УДК 330.341 .1

Тетяна Сак, кандидат економічних наук, доцент, Східносвропейський національний університет імені Лесі Українки, кафедра економіки, безпеки та інноваційної діяльності підприємства, м. Луцьк; ORCID ID: 0000-0002-7202-3426, e-mail: Sak.Tatiana@eenu.edu.ua

Наталія Грицюк, кандидат економічних наук, доцент, Східносвропейський національний університет імені Лесі Українки, кафедра економіки, безпеки та інноваційної діяльності підприємства, м. Луцьк; ORCID ID: 0000-0002-9024-6092, e-mail: natalia.hrytsiuk@eenu.edu.ua

https://doi.org/10.29038/2411-4014-2020-02-33-42

\title{
РИНОК РИТЕЙЛУ В УКРАЇНІ: ТЕНДЕНЦІЇ ТА ПЕРСПЕКТИВИ РОЗВИТКУ В УМОВАХ КРИЗИ
}

У статті проведено аналіз роздрібної торгівлі в структурі вітчизняної економіки; досліджено тенденції розвитку ринку ритейлу в Україні, наведені регіональні відмінності. На основі оцінки діяльності лідерів ринку продуктового та drogerie сегментів за регіонами та по країні загалом, визначені основні риси та тренди функціонування роздрібних мереж; наведені як позитивні, так і негативні прояви даного виду бізнесу. Окреслено основні пріоритети та можливості подальшого розвитку ринку ритейлу в Україні, серед яких: зростання темпів електронної торгівлі, впровадження сучасних інформаційних технологій та інновацій, поширення власних торгових марок.

Ключові слова: роздрібна торгівля, ритейл, ринок ритейлу, продуктовий ритейл, drogerie ритейл, електронна торгівля (e-commerce), власна торгова марка (private label), криза.

Татьяна Сак, кандидат экономических наук, доцент, Восточноевропейский национальный университет имени Леси Украинки, кафедра экономики, безопасности и инновационной деятельности предприятия, г. Луцк

Наталия Грицюк, кандидат экономических наук, доцент, Восточноевропейский национальный университет имени Леси Украинки, кафедра экономики, безопасности и инновационной деятельности предприятия, г. Луцк

\section{РЫНОК РИТЕЙЛА В УКРАИНЕ: ТЕНДЕНЦИИ И ПЕРСПЕКТИВЫ РАЗВИТИЯ В УСЛОВИЯХ КРИЗИСА}

В статье проведен анализ розничной торговли в структуре отечественной экономики; исследованы тенденции развития рынка ритейла в Украине, приведены региональные отличия. На основе оценки деятельности лидеров рынка продуктового и drogerie сегментов за регионами и по стране в целом, определены основные черты и тренды функционирования розничных сетей; приведены как позитивные, так и негативные проявления данного вида бизнеса. Очерчены основные приоритеты и возможности дальнейшего развития рынка ритейла в Украине, среди которых: рост темпов электронной торговли, внедрения современных информационных технологий и инноваций, распространения собственных торговых марок.

Ключевые слова: розничная торговля, ритейл, рынок ритейла, продуктовый ритейл, drogerie ритейл, электронная торговля (е-commerce), собственная торговая марка (private label). 
Tetiana Sak,

PhD in Economics, Associate Professor, Chair of Economics, Security and Innovation of the Enterprise, Lesya Ukrainka Eastern European National University, Lutsk

\author{
Nataliia Hrytsiuk, \\ PhD in Economics, Associate Professor, \\ Chair of Economics, Security and Innovation of the Enterprise, \\ Lesya Ukrainka Eastern European National University, Lutsk
}

\title{
RETAIL MARKET IN UKRAINE: TRENDS AND PERSPECTIVES OF DEVELOPMENT IN A CRISIS
}

Introduction. The Covid-19 pandemic, environmental changes and the economic crisis are changing the conditions and principles of business today. Nowadays, there are special requirements and restrictions need to be applied to operation of commercial enterprises, in particular - to the field of retail . The retail market should implement modern management methods, innovative technologies and sales tools to overcome the effects of the crisis.

The purpose of the article. The purpose of the article is to investigate the development trends of the retail market in Ukraine; outline the main priorities and opportunities for further effective operation.

Results. Domestic trade is an important area of economic growth, as it accumulates more than $13 \%$ of GDP in Ukraine. The modern retail market shows annual growth and it belongs to the most rapidly developed segments of the Ukrainian economy. It is represented by a wide variety of forms of interaction between seller and buyer. Some companies work on a narrow target audience, others focus on mass sales - belong to the field of retail. In 2019 retailers provided $72.5 \%$ of retail sales.

The main features of the retail market in Ukraine are: annual growth of turnover, number of shops and retail space; development of franchise networks; growth of own brands; increasing logistics capacity; low level of market concentration and high intensity of competition; emphasis on the formation of positive consumer demand; increasing corporate social responsibility.

Priorities in the development of retail market should be focused on such areas: providing safety for buyers and convenient services offline; growth of e-commerce; development of information technologies in the field of retail; increase share in trade for retailers of their own brands (private label), partial replacement of supermarkets with discount stores and shops close to the houses.

Conclusions. Ukrainian retail market shows annual growth and it is one of the fastest growing segments in Ukrainian economy. The consequences of the economic crisis and quarantine restrictions will affect the activities of Ukrainian retailers. This requires adaptation of trading methods to new conditions and intensification of innovative activities in the field of retail trade.

Key words: retail trade, retail, retail market, grocery retail, drogerie retail, e-commerce, private label, crisis.

Постановка проблеми. Сучасні виклики людству, що спричинені пандемією Covid-19, екологічними змінами та економічною кризою, змінюють умови і принципи функціонування бізнесу. Особливі вимоги та обмеження ставляться до функціонування торгівельних підприємств, зокрема сфери ритейлу. Для забезпечення безперебійної роботи, подолання наслідків кризи ринок ритейлу повинен використовувати сучасні методи управління, інноваційні технології та інструменти продажу. 3 огляду на це, обрана тематика дослідження $є$ особливо актуальною та потребує вивчення.

Мета й завдання статті - дослідити тенденції розвитку ринку ритейлу в Україні; окреслити основні пріоритети та можливості подальшого ефективного функціонування.

Аналіз останніх досліджень і публікацій. Проблеми торгівельної діяльності та ринку ритейлу висвітлили в своїх працях такі науковці, як: Антонюк Я. М., Шиндировський І. М. [1], Апопій В. В., Міщук І.П. [2], Лігоненко Л.О., Красневич Г. Л. [3], Ліпич Л.Г. [4], Федулова Л. І. [5]. Проте, назріла необхідність дослідити перспективи розвитку ринку ритейлу в умовах карантинних обмежень в Україні 2020 року і зміни поведінки покупців в майбутньому.

В Україні вагомі статистичні дослідження проводять такі організації, як Асоціація ритейлерів України (RAU) [6], GT Partners Ukraine [7] та інші. Дані щодо роздрібної торгівлі, динаміки росту мереж ритейлу та комерційної нерухомості, здійснені даними організаціями, використовуються в даній статті як джерело інформації для аналізу й оцінки. 
Виклад основного матеріалу й обгрунтування отриманих результатів дослідження. Для України внутрішня торгівля є важливою сферою економіки, адже акумулює понад 13\% (524 083 млн. грн. в 2019 році) ВВП. Разом з тим, торгівля, як вид економічної діяльності, забезпечила в 2018 році зайнятість 27,2\% населення країни [8]. Ці статистичні показники свідчать про важливість оптової та роздрібної торгівлі в економіці України, пріоритет їі розвитку та підтримки в кризових умовах.

За останні 10 років ситуація в роздрібній торгівлі залежала, насамперед, від рівня доходів населення, економічної ситуації країни. На рис. 1 чітко прослідковуються тенденція спаду фізичного обсягу товарної структури роздрібного товарообороту підприємств роздрібної торгівлі в 2009 році (світова економічна криза), 2014-2015 pр. (політична криза в Україні, початок війни на Донбасі). В 2020 році очікується суттєвий спад в зв'язку з карантинними обмеженнями через пандемією Covid19.

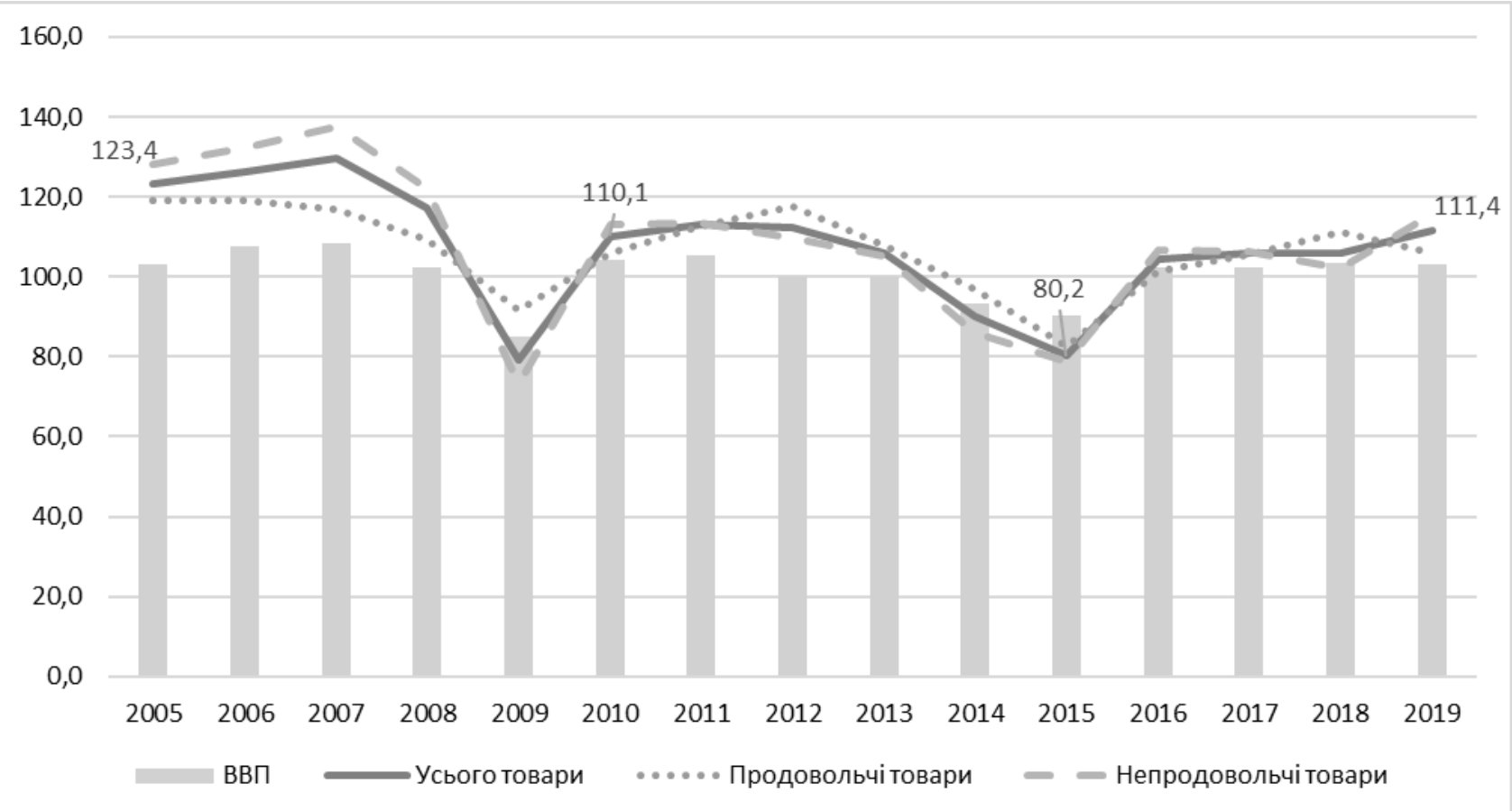

Рис. 1. Індекси фізичного обсягу товарної структури роздрібного товарообороту підприємств роздрібної торгівлі в порівнянні з індексами фізичного обсягу ВВП, у відсотках до попереднього року; у порівнянних ичінах

Джерело: сформовано за даними Державної служби статистики України [8]

Ключовим показником розвитку роздрібної торгівлі є роздрібний товарообіг, адже саме через показник товарообігу виражається суспільне визнання вартості та споживчої вартості частини суспільного продукту, який спрямований у сферу споживання [9, с. 152].

Ринок роздрібної торгівлі показує щорічне зростання і відноситься до найбільш швидко розвинених сегментів української економіки (рис. 2). На діаграмі чітко помітна тенденція до незмінного зростання товарообігу підприємств - юридичних осіб, при цьому загальний оборот роздрібної торгівлі у 2017-2018 роках зменшився в порівнянні з 2016 роком. У 2019 році оборот роздрібної торгівлі України наблизився до рівня 1,1 трлн грн, забезпечивши ріст на 10,5\%.

Сучасний ринок роздрібної торгівлі представлений широкою різноманітністю форм взаємодії між продавцем і покупцем. Частина компаній працюють на вузьку цільову аудиторію, інші орієнтуються на масові продажі, тобто відносяться до сфери ритейлу.

В своєму розумінні поняття «ритейл» ми погоджуємось з баченням відмінностей ритейлу від традиційної роздрібної торгівлі науковцями Антонюком Я. М. та Шиндировським I. М. [1, с. 23-24].

Отже, ритейл - це кінцевий продаж, орієнтований на масового покупця. Головна його особливість - пропозиція придбати товари широкого асортименту, різних торгових марок $\mathrm{i}$ напрямків, по акціях і програмах лояльності, зібрані на одній локації. 


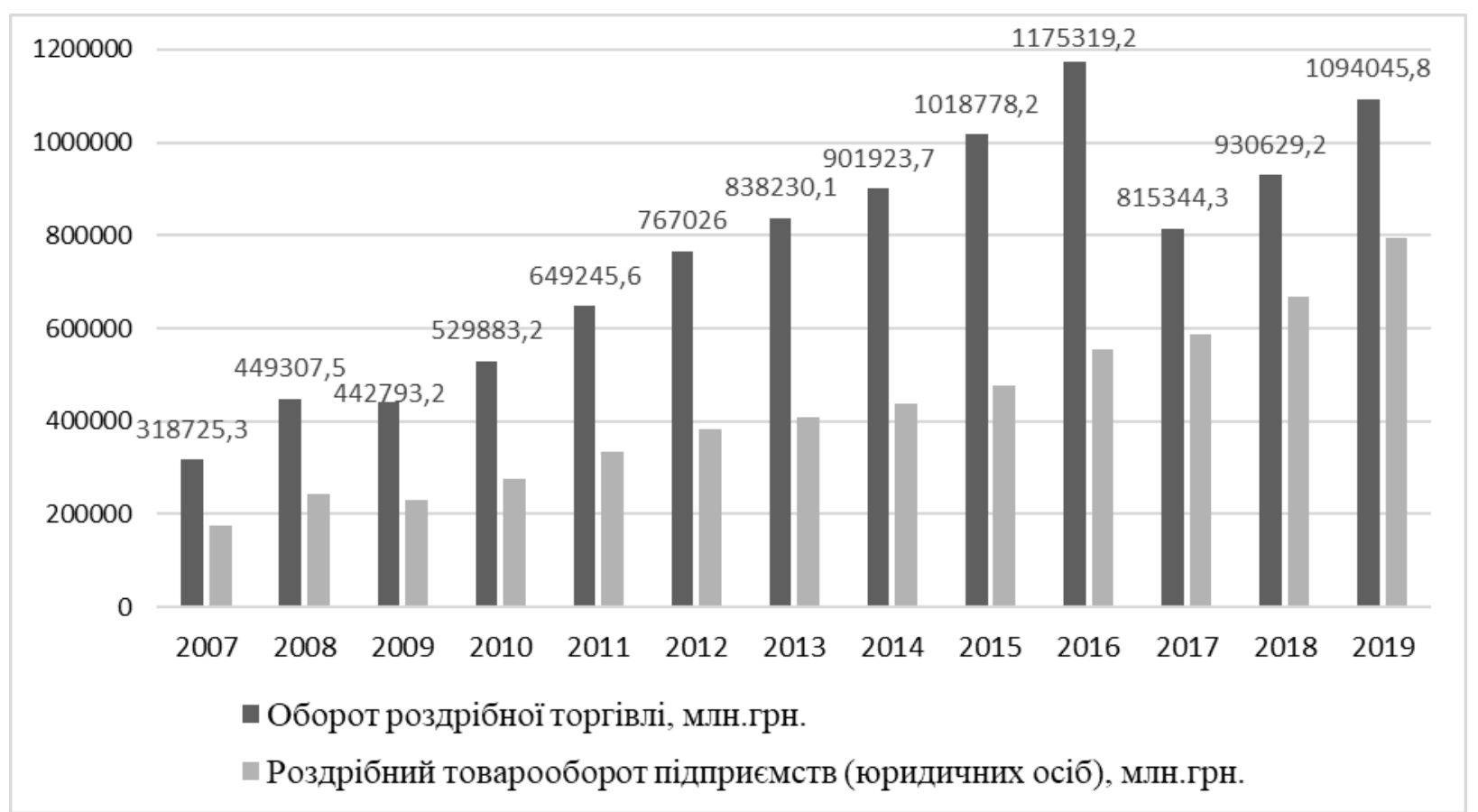

Рис. 2. Динаміка обороту роздрібної торгівлі та роздрібного товарообігу підприємств України упродовж 2007-2019 рр.

Джерело: сформовано за даними Державної служби статистики України [8]

Ринок ритейлу має суттєві переваги для споживачів:

- великий вибір товарів в одному місці;

- нижчі ціни за рахунок акцій, розпродажів, власних торгових марок (private labels);

- діючі програми лояльності, бонуси;

- організована та безпечна торгівля.

Таким чином, лише компанії, які відповідають таким параметрам, як великі обсяги продажів; трафік відвідувачів; програми лояльності; автоматизація процесів; технологічні новинки; наявна маркетинг стратегія, відносяться до ринку ритейлу.

В 2019 році ритейлери забезпечили 72,5 \% роздрібних продажів - 793,5 млрд грн, що на 18,7\% більше, ніж в 2018 році [8]. В регіональному розрізі найбільші темпи розвитку спостерігались у Київській області (без даних по м. Київ) - за рік товарообіг роздрібної торгівлі зріс на 20,8\% та склав 64,2 млрд. грн; Дніпропетровській області (13,6\%; 79,4 млрд. грн) i, власне, місто Київ (15,5\%; 185 млрд. грн) (рис. 3).

Незначні темпи росту роздрібного товарообороту характерні для ритейлерів областей Східної України (Сумська область - 5,4\%, Харківська область - 5,2\%). Лише в одній області України, Чернівецькій, відбулося скорочення виручки ритейлерів (-1,5\%).

Розглянемо основних гравців ринку продуктового ритейлу в Україні (товари сегменту FMCG) у 2019 році. За даними аналітичної компанії GT Partners Ukraine станом на кінець 2019 року лідером за кількістю магазинів в українському продуктовому ритейлі $є$ мережа АТБ-маркет, що об'єднувала 1078 магазинів. У трійку лідерів ринку входять групи Fozzy (Сільпо, Фора, Le Silpo, Thrash!, Fozzy C\&C, Favore) та Volwest (Наш Край, Spar), які на кінець 2019 року налічували 561 і 277 магазинів відповідно (табл.1). 


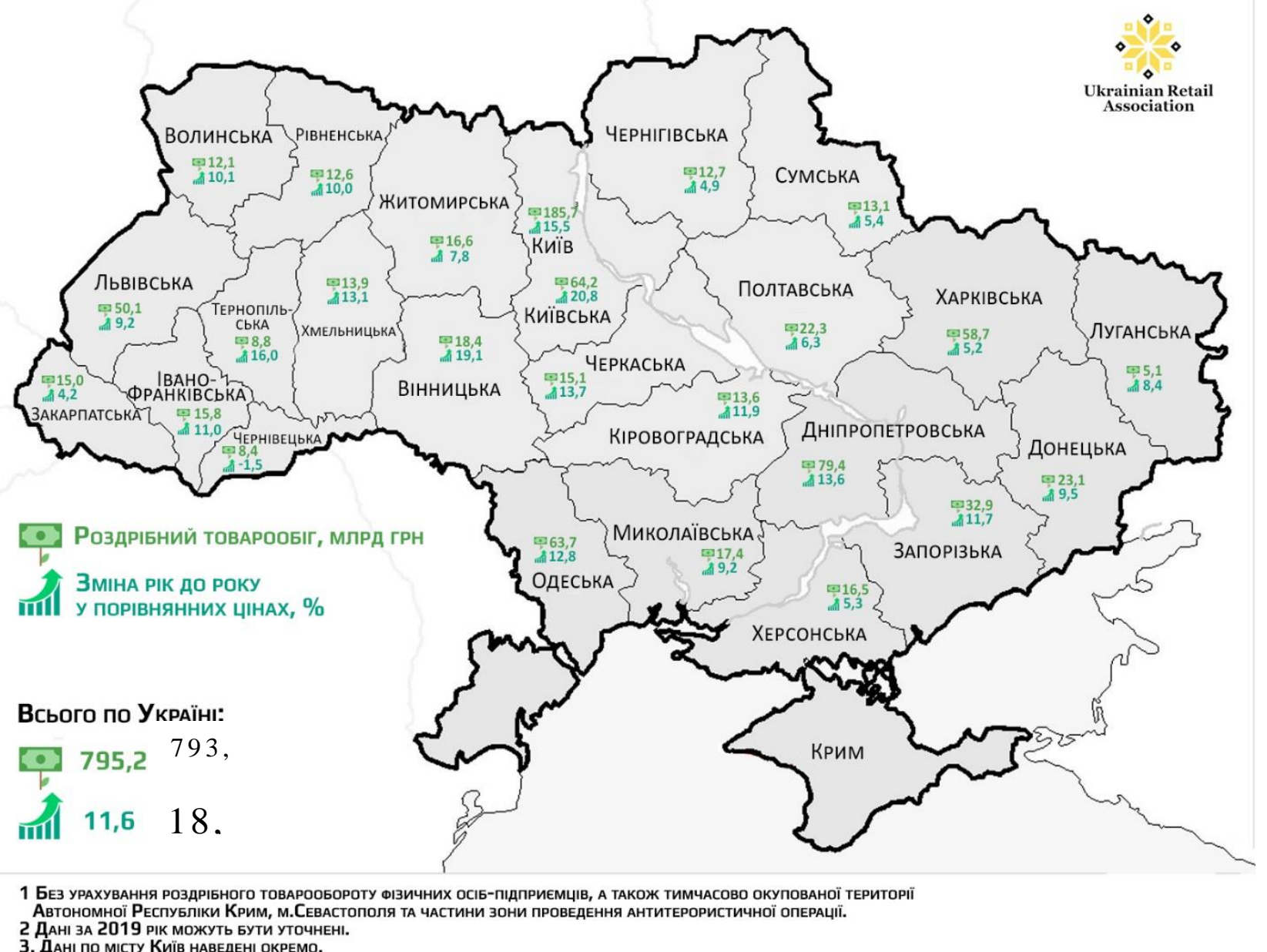
МЕ КІСТУ КИїВ НАВЕДЕНІ ОКРЕМО.

Рис. 3. Регіональна структура роздрібного товарообороту ритейлерів в Украйні у 2019 роиі Джерело: за даними Асоціації ритейлерів України (RAU) [6]

Таблиия 1

Лідери ринку продуктового ритейлу в Україні у 2018-2019 рр. за кількістю магазинів

\begin{tabular}{|c|c|c|c|c|c|}
\hline \multirow{2}{*}{ Рейтинг } & \multirow{2}{*}{ Компанія } & \multirow{2}{*}{ Мережі } & \multicolumn{2}{|c|}{ Кількість магазинів } & \multirow{2}{*}{$\begin{array}{c}\text { Темп } \\
\text { приросту } \\
\text { за рік, \% }\end{array}$} \\
\hline & & & 2018 рік & 2019 рік & \\
\hline 1 & ТОВ «АТБ-маркет» & АТБ, АТБ express & 990 & 1078 & 8,9 \\
\hline 2 & Fozzi Group & $\begin{array}{l}\text { Сільпо, Фора, Fozzi, Le Silpo, } \\
\text { Thrash!, Favore }\end{array}$ & 540 & 561 & 3,9 \\
\hline 3 & Volwest Group & $\begin{array}{l}\text { Наш край, SPAR, Наш Край } \\
\text { ЕКСПРЕС }\end{array}$ & 247 & 277 & 12,1 \\
\hline 4 & $\begin{array}{l}\text { ТОВ ТВК } \\
\text { «Львівхолод» }\end{array}$ & $\begin{array}{l}\text { Рукавичка, Під Боком, } \\
\text { Рукавичка S }\end{array}$ & 141 & 159 & 12,8 \\
\hline 5 & TOB «EKO» & ЕКО Маркет, Симпатик & 114 & 148 & 29,8 \\
\hline 6 & TOВ «Опторг-15» & Делві & 109 & 112 & 2,8 \\
\hline 7 & ТОВ «Арітейл» & Коло & 52 & 105 & 101,9 \\
\hline 8 & ТОВ «ЛК-ТРАНС» & ЛотОК & 84 & 91 & 8,3 \\
\hline 9 & ТОВ «Модерн-Трейд» & $\begin{array}{l}\text { Копійка, Копійка-мінімаркет, } \\
\text { Santim }\end{array}$ & 86 & 90 & 4,7 \\
\hline 10 & TOВ «Таврія В» & Таврія-В, Космос & 76 & 86 & 13,2 \\
\hline
\end{tabular}

Джерело: розраховано за даними Асоціації ритейлерів України (RAU) [6], GT Partners Ukraine [7] 
В 2019 році продуктові мережі відкрили 697 магазинів в Україні, що на 192 магазини більше, ніж в 2018 році. В 2018 році в Україні було відкрито 505 магазинів, а в 2017 році - 511. 3 відкритих 697 торгових точок, 518 - це магазини в нових локаціях, інші 179 змінили назву в результаті ребрендингу, поглинання чи зміни прав оренди. Лідерами за темпами росту в 2019 році стали мережа магазинів біля дому «Коло» ТОВ «Арітейл» $(101,9 \%)$; ТОВ ТВК «Львівхолод», мережі «Рукавичка», «Під Боком», «Рукавичка $\mathrm{S} »(12,8 \%) ; \mathrm{TOB}$ «ЕКО» $(29,8 \%)$.

Лідерство за регіонами частково відрізняється (табл. 2).

Таблиия 2

Характеристика головних продуктових ритейлерів за регіонами України на 01.01.2020 р.

\begin{tabular}{|c|c|c|c|}
\hline Компанія & Мережі & $\begin{array}{l}\text { Кількість } \\
\text { магазинів } \\
\end{array}$ & $\begin{array}{c}\text { Торгова } \\
\text { площа, кв.м. }\end{array}$ \\
\hline \multicolumn{4}{|c|}{ Місто Київ } \\
\hline Fozzi Group & Сільпо, Фора, Fozzi, Le Silpo, Thrash!, Favore & 199 & 169500 \\
\hline ТОВ «АТБ-маркет» & АТБ, АТБ express & 143 & 52980 \\
\hline $\begin{array}{l}\text { ТОВ «Ашан Україна } \\
\text { Гіпермаркет» }\end{array}$ & Ашан, Мій Ашан & 12 & 98670 \\
\hline Novus Україна & NOVUS, NOVUS express & 28 & 72350 \\
\hline Retail Group & Велика кишеня, Велмарт & 27 & 41425 \\
\hline \multicolumn{4}{|c|}{ Північна Україна (без м.Київ) } \\
\hline Fozzi Group & Сільпо, Фора, Fozzi, Le Silpo, Thrash!, Favore & 155 & 98600 \\
\hline ТОВ «АТБ-маркет» & АТБ, АТБ express & 139 & 61000 \\
\hline TOB «EKO» & ЕКО Маркет, Симпатик & 40 & 38040 \\
\hline Novus Україна & NOVUS, NOVUS express & 9 & 23000 \\
\hline \multicolumn{4}{|c|}{ Центральна Україна } \\
\hline ТОВ «АТБ-маркет» & АТБ, АТБ express & 129 & 60615 \\
\hline ТОВ «Август-Плюс» & МаркетОТП & 71 & 31500 \\
\hline Fozzi Group & Сільпо, Фора, Fozzi, Le Silpo, Thrash!, Favore & 22 & 29645 \\
\hline НПП «Аргон» & ГРОШ, Грош експрес, К-Маркет, Економ & 26 & 18600 \\
\hline Retail Group & Велика кишеня, Велмарт & 8 & 19950 \\
\hline \multicolumn{4}{|c|}{ Південна Україна } \\
\hline ТОВ «АТБ-маркет» & АТБ, АТБ express & 121 & 59200 \\
\hline ТОВ «Модерн-Трейд» & Копійка, Копійка-мінімаркет, Santim & 90 & 48550 \\
\hline ТОВ «Таврія В» & Таврія-В, Космос & 78 & 130125 \\
\hline Fozzi Group & Сільпо, Фора, Fozzi, Le Silpo, Thrash!, Favore & 49 & 66465 \\
\hline \multicolumn{4}{|c|}{ Західна Україна } \\
\hline Volwest Group & Наш край, SPAR, Наш Край ЕКСПРЕС & 186 & 31550 \\
\hline $\begin{array}{l}\text { ТОВ ТВК } \\
\text { «ьвівхолод» }\end{array}$ & Рукавичка, Під Боком, Рукавичка S & 159 & 37380 \\
\hline ТОВ «АТБ-маркет» & АТБ, АТБ express & 110 & 62820 \\
\hline Fozzi Group & Сільпо, Фора, Fozzi, Le Silpo, Thrash!, Favore & 48 & 72630 \\
\hline $\begin{array}{l}\text { ТОВ «ПАККО } \\
\text { Холдинг» }\end{array}$ & Вопак, Пакко & 63 & 29575 \\
\hline \multicolumn{4}{|c|}{ Східна Україна } \\
\hline ТОВ «АТБ-маркет» & АТБ, АТБ express & 435 & 213355 \\
\hline Fozzi Group & Сільпо, Фора, Fozzi, Le Silpo, Thrash!, Favore & 88 & 140070 \\
\hline ТОВ «Омега» & VARUS, VARUS-market, Планета & 67 & 68440 \\
\hline $\begin{array}{l}\text { Metro Cash \& Carry } \\
\text { Ukraine }\end{array}$ & METRO Cash \& Carry & 7 & 54000 \\
\hline $\begin{array}{l}\text { ТОВ «Ашан Україна } \\
\text { Гіпермаркет» }\end{array}$ & Ашан, Мій Ашан & 7 & 53750 \\
\hline
\end{tabular}

Джкерело: за даними Асоціації ритейлерів України (RAU) [6], GT Partners Ukraine [7] 
Велике значення відіграє походження і місце старту компанії. Так, у Києві та Північній Україні найпоширеніші торгові мережі компанії Fozzi Group, центральний офіс якої знаходиться в столиці. На заході країни лідирують місцеві ритейлери - Volwest Group та ТОВ ТВК «Львівхолод».

Таким чином, основними рисами ринку продуктового ритейлу в Україні є:

- ерічне зростання товарообороту, кількості магазинів та торгівельних площ;

- розвиток франчайзингових мереж;

- ріст власних торгових марок;

- нарощування логістичних потужностей;

- низький рівень концентрації ринку та висока інтенсивність конкуренції.

В секторі непродовальчого ритейлу в Україні виділяються мережі, що продають товари для краси та здоров'я, так званий сектор drogerie. Даний ринок є одним з найбільш зростаючим. Так, за 2018 рік мережеві оператори drogerie відкрили 350 магазинів. Для порівняння: у 2017 році в країні було відкрито 308 нових магазинів (в 2016 р. - 455).

На ринку товарів для краси та здоров'я, на відміну від ринку товарів сегменту FMCG, існує трійка лідерів за кількістю магазинів, темпам розвитку і географічним охопленням: мережі EVA, Watsons, ProStor. Дані щодо розвитку топ-5 українських мереж сектору drogerie, наведені в табл. 3 .

Лідери ринку сектору drogerie в Україні у 2018-2019 рр. за кількістю магазинів

\begin{tabular}{|c|c|c|c|c|c|}
\hline \multirow{2}{*}{ Рейтинг } & Компанія & Мережі & 2018 рік & 2019 рік & $\begin{array}{c}\text { приросту за } \\
\text { рік, \% }\end{array}$ \\
\cline { 4 - 6 } & ТОВ «Руш» & EVA & 770 & 974 & 26,5 \\
\hline 2 & ТОВ «ДЦ Україна» & Watsons & 429 & 416 & $-3,0$ \\
\hline 3 & ТОВ «Стиль Д» & ProStor & 332 & 336 & 1,2 \\
\hline 4 & $\begin{array}{c}\text { ТОВ «Торгова мережа } \\
\text { Копійочка» }\end{array}$ & Копійочка & 168 & 183 & 8,9 \\
\hline 5 & ТОВ «Шик і блиск» & Шик і блиск & 151 & 143 & $-5,3$ \\
\hline
\end{tabular}

Джерело: розраховано за даними Асоціації ритейлерів України (RAU) [6], GT Partners Ukraine [7], офіційних сайтів компаній

Абсолютним рекордсменом 2019 року за темпами розвитку стала мережа магазинів EVA. B цілому компанія відкрила 218 нових торгових точок. При цьому чистий приріст магазинів за рік був трохи меншим: на кінець 2019 року EVA налічувала 974 магазини.

Міжнародна компанія Watsons, яка посідає друге місце за кількістю магазинів в Україні, обрала іншу стратегію розвитку - підвищення операційної ефективності та освоєння нових форматів магазинів, замість збільшення кількості точок продажу. За підсумками 2019 року компанія скоротила свою роздрібну мережу на 13 магазинів.

Мережа Prostor в 2019 році відкрила 24 нові торгові точки. Однак чистий приріст по мережі склав лише 4 магазини [10].

Як і основні продуктові ритейлери, сегмент drogerie в географічному плані основну увагу зосереджує на Західній Україні (Волинська, Рівненська, Тернопільська, Львівська, Хмельницька, Івано-Франківська, Чернівецька, Закарпатська області). В даному регіоні почало працювати 34,5\% всіх нових об'єктів [10].

Отже, основними трендами drogerie-ритейлу в Україні є:

- лідерство мережі EVA у всіх регіонах, крім західних областей (тут переважає мережа магазинів «Копійочка»);

- активне розширення мереж;

- акцент на формування позитивного споживчого попиту; 
- підвищення соціальної відповідальності бізнесу.

До негативних проявів функціонування ринку ритейлу в Україні варто віднести низьке охоплення продаж вітчизняних товарів. Крім того, частка продажу підприємствами роздрібної торгівлі товарів, які вироблені на території України, щороку зменшується (рис. 4).

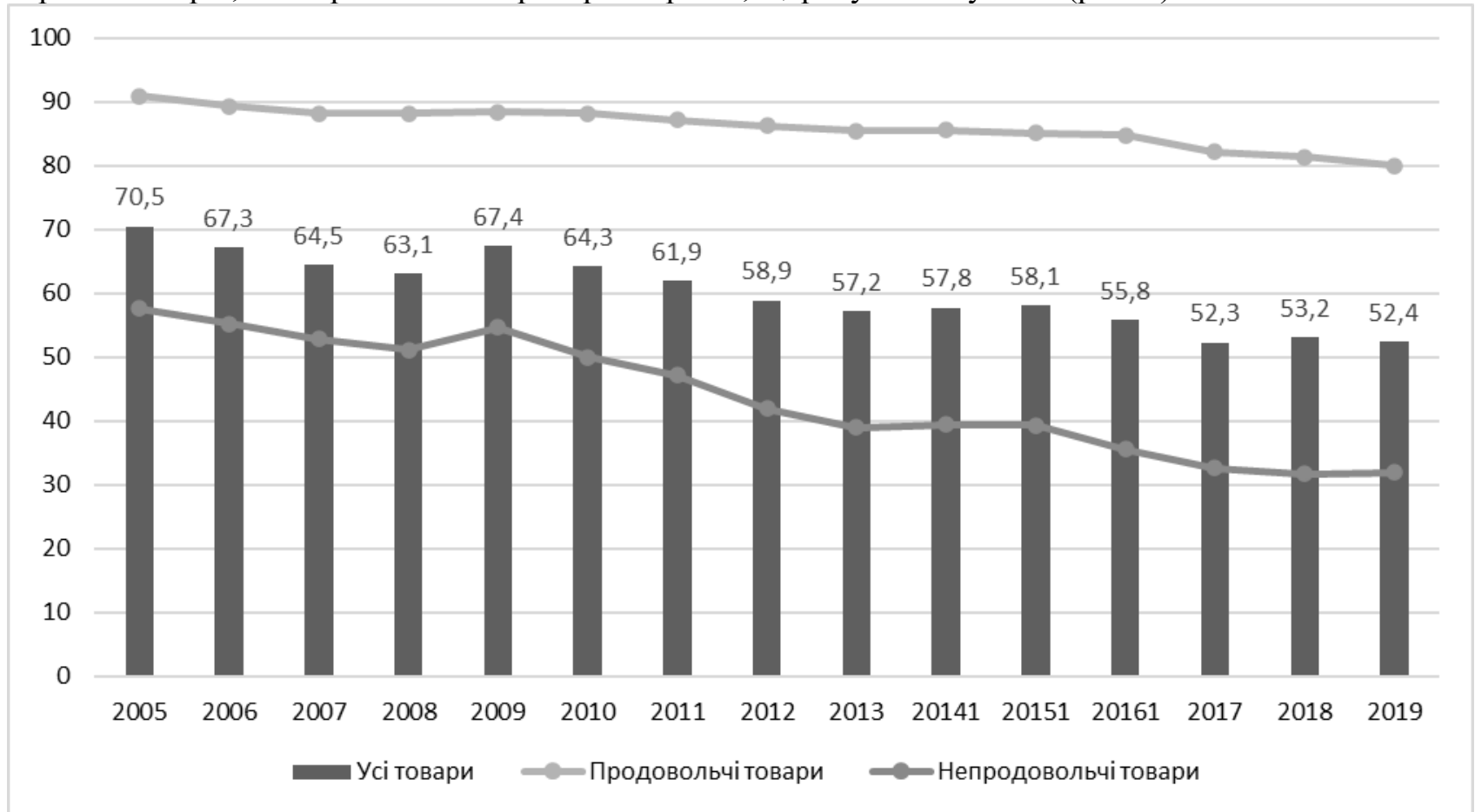

Рис. 4. Частка продажу підприємствами роздрібної торгівлі товарів, які вироблені на території Украӥни

Джерело: сформовано за даними Державної служби статистики України [8]

Згідно даних Державної служби статистики України, у 2019 році в роздрібній мережі було продано лише $52,4 \%$ вітчизняних товарів, в тому числі непродовольчих товарів частка продажу склала лише $32 \%$ [8]. Проте, в зв'язку з закриттям кордонів під час пандемії Covid-19, можливе зростання частки вітчизняних товарів в структурі продаж з 2020 року.

Отже, пріоритетами розвитку ринку ритейлу мають стати:

1. Організачія безпеки для покупия та зручності обслуговування при оffline торгівлі.

Беззаперечним є той факт, що навіть після відміни карантинних обмежень, безпечність перебування в громадських місцях стане скоріше принципом, ніж вимогою чи правилом.

2. Зростання темпів електронної торгівлі (е-соттегсе).

Сегмент електронної комерції в Україні займає незначну частку в загальному обсязі роздрібної торгівлі (4\%). Проте, online торгівля є одним 3 найбільш перспективним і швидкозростаючим напрямком ритейлу, що має ряд переваг порівняно з класичними магазинами.

В праці [4] автори наголошують на перспективах електронного бізнесу в Україні, тому зазначають, що ритейлери повинні бути готовими оновити свою інформаційну систему для задоволення мінливого попиту на ринку та максимального задоволення потреб клієнтів.

Одночасно з розвитком online торгівлі виникає потреба якісних послуг кур'єрської доставки.

3. Розвиток інформаційних технологій (IT) в сфері ритейлу.

Застосування інформаційних технологій в роздрібній торгівлі зумовлює ефективність торговельної організації. Інформаційні продукти, що їх застосовують в торгівлі, не лише спрощують операційну діяльність підприємства, а й забезпечують управління взаєминами із клієнтами, постачальниками, контролюють процес продаж.

Федулова Л.І. нинішні тенденції в роздрібній торгівлі (укрупнення мереж, регіональна віддаленість об'єктів, національний масштаб діяльності передових ритейлерів, розвиток мультиформатності в рамках однієї мережі, прихід в Україну таких нових форматів, як DIY, 
посилення розповсюдження супер- і гіпермаркетів) називає передумовами до зміни вимог до інформаційно-технологічної інфраструктури мережевого ритейлу [5, с. 32]. Автор до трендів формування та розвитку IT в торгівельних мережах відносить:

- розвиток IT, що сприяють мінімізації взаємодії між покупцями й обслуговуючим персоналом (термінали самообслуговування, селф-сервіси, інформаційні кіоски, використання прайс-чекерів);

- IT-підтримка програм лояльності клієнтів, збору й обробки персональних даних клієнта;

- провадження систем особистої участі клієнтів (DMA);

- широке використання соціальних мереж в просуванні товарів та комунікаціях; 27-29].

- розвиток хмарних сервісів, що істотно прискорюють розв'язання інтеграційних завдань $[5, \mathrm{c}$.

4. Збільшення частки в товарообороті ритейлерів власних торгових марок.

Позиціонування private label як товару з меншою ціною та якістю, яку контролює ритейлер, дозволить утримати позиції роздрібним організаціям під час економічного спаду, коли покупці починають економити на придбанні продукції відомих торгових марок.

5. Часткове заміщення супермаркетів дискаунтерами $i$ «магазинами біля дому» 3 удосконаленням сервісу обслуговування на основі принципу «позитивних емоиій».

Даний тренд буде продовжуватися, адже доступність, безпечність, зручність та емоції стають основними критеріями мотивації на рівні таких, як ціна і якість товару.

6. Нарощення логістичних потужностей.

Доцільними $є$ інвестиції в розширення складів, удосконалення транспортної логістики, адже швидкість доставки товару до кінцевого споживача, контроль ланцюга поставок і скорочення витрат на логістику будуть ключовими факторами успіху в конкурентній боротьбі.

Висновки й перспективи подальших досліджень. Ринок ритейлу в Україні показує щорічне зростання і відноситься до найбільш швидко розвинених сегментів української економіки, забезпечуючи 72,5 \% роздрібних продажів в 2019 році. Виокремлені основні тренди продуктового та drogerie-ритейлу в Україні: щорічне зростання товарообороту, кількості магазинів та торгівельних площ; розвиток франчайзингових мереж; ріст власних торгових марок; нарощування логістичних потужностей; низький рівень концентрації ринку та висока інтенсивність конкуренції; акцент на формування позитивного споживчого попиту; підвищення соціальної відповідальності бізнесу.

Основними пріоритетами в розвитку ринку ритейлу мають стати такі напрями як:

1. Організація безпеки для покупця та зручності обслуговування при offline торгівлі.

2. Зростання темпів електронної торгівлі (е-соmmerce).

3. Розвиток інформаційних технологій в сфері ритейлу.

4. Збільшення частки в товарообороті ритейлерів власних торгових марок (private label).

5. Часткове заміщення супермаркетів дискаунтерами i «магазинами біля дому».

6. Нарощення логістичних потужностей.

Наслідки економічної кризи та карантинних обмежень вплинуть на діяльність українських ритейлерів, що вимагає адаптації методів торгівлі до нових умов, активізації інноваційної діяльності в сфері роздрібної торгівлі. 3 огляду на це, перспективним напрямом подальших досліджень $\epsilon$ детальне вивчення електронної торгівлі як способу диверсифікації діяльності в роздрібній мережі.

\section{Джерела та література}

1. Антонюк Я. М., Шиндировський І. М. Тенденції розвитку ритейлу в Україні. Підприємництво $i$ торгівля. 2019. Вип. 24. С. 22-30.

2. Структурні зміни та сучасні тенденції розвитку внутрішньої торгівлі України: монографія /Апопій В. В., Міщук І. П., Антонюк Я. М. та ін.; за ред. проф. Апопія В. В. Львів : «Новий Світ -2000», 2017. 440 с.

3. Лігоненко Л., Красневич Г. Інноваційний вектор розвитку торгівлі в Україні. Товари і ринки. 2011. № 1. C. 7-14.

4. Lubov Lipych, Anna Mokhniuk. E-business in Ukraine: peculiarities, tendencies, prospects. Економічний часопис Східноєвропейського національного університету імені Лесі Украӥнки. 2020. Том 1. № 21. С. 74-79.

5. Федулова Л. Інформаційно-технологічна інфраструктура рітейлу. Вісник Київського національного торговельно-економічного університету. 2017. № 4. С. 21-42.

6. Офіційний сайт Асоціації ритейлерів України. URL: https://rau.ua (дата звернення: 26.04.2020). 
7. GT Partners Ukraine. URL:http://allretail.ua/ (дата звернення: 26.04.2020)/

8. Офіційний сайт Державної служби статистики України. URL: http://www.ukrstat.gov.ua/ (дата звернення: 24.04.2020).

9. Силкіна Ю. О. Проблеми та перспективи розвитку ринку роздрібних торговельних мереж в Україні. Науковий вісник Міжнародного гуманітарного університету. Серія : Економіка і менеджмент. 2017. Вип. 25(1). С. $152-157$.

10. Рекордний рік: скільки магазинів відкрили найбільші мережі України в 2019-мy. URL: https://rau.ua/novyni/skolko-magazynov-otkryly-2019/ (дата звернення: 18.04.2020).

\section{References}

1. Antonyuk Ya. M. \& Shyndyrovsky I. M. (2019). Tendenciji rozvytku rytejlu v Ukrajini [Trends of retail development in Ukraine]. Pidpryjemnyctvo i torghivlja - Entrepreneurship and commerce, 24, 22-30 [in Ukrainian].

2. Strukturni zminy ta suchasni tendentsii rozvytku vnutrishn'oi torhivli Ukrainy [Structural changes and current tendencies of development of domestic trade of Ukraine], Apopij V. V., Mischuk I. P., Antoniuk Ya. M. ta in.; za red. prof. Apopiia V. V. (2017), «Novyj Svit-2000», L'viv, 440 [in Ukrainian].

3. Ligonenko L. \& Krasnevych G. (2011). Innovacijnyj vektor rozvytku torgivli v Ukrai'ni [Innovative vector of commerce development in Ukraine]. Tovary i rynky - Goods and markets, 1, 7-14 [in Ukrainian].

4. Lubov Lipych, Anna Mokhniuk (2020). E-business in Ukraine: peculiarities, tendencies, prospects. Ekonomichnyj chasopys Skhidnojevropejsjkogho nacionaljnogho universytetu imeni Lesi Ukrajinky -Economic Journal of Lesya Ukrainka Eastern European National University, 21, $74-79$ [in English].

5. Fedulova L. (2017) Informacijno-tekhnologhichna infrastruktura ritejlu [Retail information technology infrastructure]. Visnyk Kyjivsjkogho nacionaljnogho torghoveljno-ekonomichnogho universytetu - Bulletin of the Kyiv National University of Commerce and Economics, 4, 21-42 [in Ukrainian].

6. Sait «Asotsiatsiia ryteileriv Ukrainy» [Website of the Ukrainian Retailers Association]. rau.ua. Retrieved from https://rau.ua [in Ukrainian].

7. GT Partners Ukraine. allretail.ua. Retrieved from http://allretail.ua/ [in Ukrainian].

8. Sait «Derzhavna sluzhba statystyky Ukrainy» [State «Statistics Service of Ukraine»]. ukrstat.gov.ua. Retrieved from http://ukrstat.gov.ua [in Ukrainian].

9. Sylkina Yu.O. (2017). Problemy ta perspektyvy rozvytku rynku rozdribnykh torghoveljnykh merezh $v$ Ukrajini. [Problems and perspectives for the development of the market for retail trade chains in Ukraine] Naukovyj visnyk Mizhnarodnogho ghumanitarnogho universytetu - Scientific Bulletin of the International Humanities University, 25(1), 152-157 [in Ukrainian].

10.Rekordnyi rik: skilky mahazyniv vidkryly naibilshi merezhi Ukrainy v 2019-mu [Record year: how many stores opened Ukraine's largest networks in 2019]. Retrieved from https://rau.ua/novyni/skolko-magazynov-otkryly2019/ [in Ukrainian].

Стаття надійшла до редакції 06.05.2020 p. 